\title{
CHALLENGES ENCOUNTERED BY STUDENT TEACHERS IN PRACTICING
} TEACHING

\author{
Dr. Shaban Aldabbus \\ Bahrain Teachers College, University of Bahrain
}

\begin{abstract}
This study investigated the challenges encountered by student teachers during their teaching practice. The sample of the study comprised 4 supervisors and 12 student teachers enrolled in the final semester in the Faculty of Education at Tripoli University. The student teachers studied different content and method courses during their studying journey in the college and did some micro teaching as a prerequisite for the teaching practice. A questionnaire and a semi-structured interview were employed for data collection. Data analysis revealed that although there was a noticeable application of what they had studied in the college, some remarkable challenges were found. For instance, lack of cooperation between the student teachers and school principal and cooperative teachers, lack of confidence, lack of classroom management skills, little guidance, and support from the part of the supervisors. Finally, the study provided several suggestions that could help eradicate or at least minimize the effect of these challenges on the quality of teaching practice.
\end{abstract}

KEYWORDS: Teaching practice, student-teacher, challenges

\section{INTRODUCTION}

Teaching Practice (TP) is a common feature of any teacher education program that ends up providing graduates with a recognized teaching certificate. It is the practical use of teaching methods and strategies that the student-teacher learned in the college. During teaching practice, a student-teacher is allowed to try the art of teaching before getting into the real world of the teaching profession (Ebrahim, et al, 2017). Teaching practice goes beyond just knowing what to teach and knowing how to teach, however, the purpose of teaching practice is to develop several competencies in the trainee teacher which include interpersonal, pedagogical, intercultural, and psychological competencies (Chikezie, 2017).

According to the Faculty of Education at Tripoli University, the teaching practice program aims to a) provide student teachers with an opportunity to apply what they have already studied in previous semesters, b) provide an opportunity for evaluating the student potential as a teacher, and provide them with constructive feedback, c) provide the future teacher with practical experience in school to overcome the problems of discipline and enable them to cope with unfamiliar situations.

\section{Research problem}

Student-teacher practice has been implemented in many faculties of education in Libya for decades. Students spend at least four years of systematic learning of different subjects with little concentration on actual teaching practice. It has been observed that some students feel reluctant to practice teaching in a real classroom situation. Although they study courses like methods and strategies of teaching some student teachers are still incapable of putting theories into practice. However, this study aims to find out the challenges which student teachers in the 
Faculty of Education at Tripoli University encounter during their teaching practice. It also aims to provide suggestions for teaching practice office and student-teachers to overcome these challenges

\section{Research questions}

- What are the potential challenges that student-teachers encounter during their teaching practice?

- What are the possible suggestions to overcome these challenges, if there are any ?

\section{LITERATURE REVIEW}

Teaching Practice (TP) is one of the core courses in which teacher education institutions send student-teachers to different schools to implement what they have studied under the supervision of experienced instructors. According to Davidson (2005), "teaching practice can be defined as the system by which teachers in training are subjected to a systematic exposure to actual classroom situation". In the same vein, Elmabruk (2020) defined teaching practice "as the opportunity given to trainee teachers to apply the knowledge and skills they acquired during the theoretical part of their preparation period in the hope to become proficient practicing teachers"'. However, through looking at the vision and mission of several teacher preparation institutions all over the world, it becomes clear that the main goal for those institutions is to prepare teachers to be able to teach using modern teaching methods and technology. This can only be achieved by providing student teachers with sufficient theoretical information besides helping them to acquire the skills of teaching, classroom management, and the use of technology. However, it has been stated by Davidson (2005) that any knowledge gained by individuals will remain worthless unless the person who acquires it has the chance to apply that knowledge in different contexts. Therefore, TP plays a fundamental role in "enabling prospective teachers to contribute immensely to the teaching profession" (Chikezie, 2017).

Hence, TP is considered to be the cornerstone in the teaching and learning program in the Faculty of Education at Tripoli University because student teachers have to show their abilities and skills in applying the knowledge and theories they have mastered during their study in the college. Student teachers usually go for teaching practice in their final semester. It lasts for approximately six weeks, one week is dedicated to observation and five weeks are spent in actual teaching (Elmabruk, 2018). Before starting their actual teaching practice in schools, they are given opportunities to do some micro-teaching in the college with their classmates. Each student has to give at least two lessons in the presence of the course instructor. Based on their performance in micro-teaching, they receive constructive feedback from classmates as well as the instructor. Only those who pass teaching strategies I and II courses can go for the teaching practice in schools in the following semester. Therefore, each student teacher is required to teach at least 8 to 10 lessons per week and each lesson lasts for 40 minutes giving a total of 50 class hours.

Each student teacher is supervised and assessed by two supervisors. One Academic Supervisor (AS) from the department that the student-teacher belongs to, and an Education Supervisor (ES) from the Education and Psychology Department. The final assessment mark by the AS is given out of 50 to which 40 marks are added by the ES and another 10 marks by the TP school 
headmaster, thus giving a total of 100 percent (Elmabruk, 2018). However, a pass in teaching practice is a precondition of graduation in the college.

\section{Challenges facing student-teacher during teaching practice}

Although most student teachers look at teaching practice as an interesting experience in their lives and they look forward to standing in front of a group of students and implementing what they have studied during their long journey in the college, yet it is not without problems and challenges. Therefore, many researchers from different contexts have addressed in detail those challenges which the student-teachers encounter during the period of teaching practice. For instance, SarÕçobana (2010) listed several challenges that student teachers face in their TP such as putting theories into practice, choosing the appropriate method of teaching, and checking whether the learning objectives were achieved or not. Lack of facilities and supplementary materials in schools and misunderstanding on the part of the school administration were among the challenges. Besides that, dealing with a big number of students in the class, a poor lesson plan, and designing differentiated tasks were also common (Ball et al., 2008; \& Scott, 2015). Al-Momani's (2016) study at KSA investigated teaching practice challenges at the Faculty of Education from supervisors and pre-service teachers' perspectives. The findings demonstrated that fear of teaching, communication skills, and putting theories into practice were common challenges.

Furthermore (Nasir \& Zafar 2018) stated that student teachers had challenges in managing their class time. That is, distributing appropriate time for each activity, wasting too much time checking student's homework, giving instructions, and taking attendance. They added that some student teachers still behaved as if they were university students and in turn, they preferred to be treated by the school administration as teachers maybe because they were not aware of the terms and conditions of discipline and the code of conduct in schools. On the other hand, they noted that $75 \%$ of the participants were interested in teaching and tried a combination of teaching methods other than the ones dominant in schools. They also observed the keenness of the student teachers to communicate with their supervisors to obtain feedback on time. Interestingly, some student teachers were trying to build a good relationship with their students without keeping enough distance between them and the students and, therefore, they did not get enough respect from students because they looked at them as university students and not as teachers yet (Chikezie, 2017).

\section{RESEARCH METHODOLOGY}

The approach used to answer the set of research questions was a qualitative case study in which two data collection tools were utilized. A questionnaire was completed by 12 student teachers and 4 supervisors and a semi-structured interview was conducted with some of the participants whenever more clarification is required. This approach was adopted because it enabled the researcher to interact with the participants and gain more in-depth information and understanding of the situation.

\section{Setting and Participants}

The participants of the study are final semester students in the English Department, Faculty of Education, Tripoli University. The total number of participants is 12 student teachers and 4 supervisors, 2 of them are academic and 2 education. The student teachers had almost the same 
background, i.e they used the same L1 and learned the same content and method courses. They were selected randomly and all of them were willing to take part in the study. The supervisors are full-time instructors in the Faculty of Education with a minimum of three years of supervision experience.

\section{Significance of the study}

It was hoped that getting detailed information about student teachers while doing TP would make a significant contribution to knowledge within teacher education in the Faculty of Education at Tripoli University by providing useful information about actual practice towards the training of students. The researcher also hoped that insights gained through the study could stimulate further study. However, the findings of the study cannot be generalized to other student teachers from other teacher training programs, because of the small sample used.

\section{Data analysis}

Data were collected from twelve student teachers and four supervisors. Both a questionnaire with open-ended questions and semi-structured interviews were employed for gathering the data. To answer the key question (What are the potential challenges that student-teachers encounter during their teaching practice?), data collected were analyzed, combined, and classified into three main themes: challenges related to schools, challenges related to supervisors, and challenges related to student teachers, as illustrated below:

\section{Challenges related to schools}

One of the supervisors claimed that the school doubts the ability of the student teachers to carry out the job properly and worries about not completing the syllabus. Also, the school does not favor the change of teachers in the middle of the course which involves new methods, techniques, and assessments. This in turn would affect their students. On the other hand, the data revealed that some student teachers are enthusiastic about their new careers and want to apply modern methods of teaching. This is often met with contempt and refusal (sometimes jealousy) from the side of the schoolteacher. The student teachers are often discouraged to use new strategies for teaching English. They are often accused by the schoolteacher of wasting time and not carrying on with the syllabus. Therefore, neither the school nor the schoolteachers permit activities that require preparation, movement, noise such as competition activities. One student teacher sadly said that "we often go through hard times trying to make a balance between quantity and quality of teaching". However, it is well known that the Ministry of Education inspectors often stress quantity over quality, so the schoolteachers' main concern is to finish the syllabus within the allocated time (Confait, 2015). Besides, the school does not support the trainees by providing them with equipment or materials which are sometimes available but locked away as claimed by one of the supervisors. This issue sounds to be international as it is found by other researchers like Adeyanju (2012) and Ngada (2014) who reported that some schools did not provide enough facilities and adequate allowances required for successful teaching practice. However, school- administration needs to ensure that student teachers are supported during their teaching practice so they can make the most of this opportunity (Abongdia at el., 2015).

The findings of this study further show that there is sometimes interference from the side of the schoolteacher in teaching. For example, one of the student teachers said that "in one case the schoolteacher was sitting in the back of the classroom and offering translation in Arabic 
to the class while I was teaching, thus not giving the chance to me to deliver the lesson as I planned thinking that she was helping me to convey the content to my students'.' Other student teachers stated that "we were able to build warmer rapport with the students, but this affected negatively our relationship with the schoolteachers when some students asked us to continue with them till the end of the semester".

\section{Challenges related to supervisors}

Student teachers are expected to receive constructive feedback from their supervisors to enable them to make corrections and the appropriate adjustments of their professional abilities (Mosas, 2019). However, some of the participants complain about not getting adequate feedback from their supervisors. In many cases, the supervisor leaves without comments or giving too broad comments that do not guide the trainee. This is in line with what has been found by Nakpodia, (2011) that some supervisors do not even have time to sit down and discuss their observations and comments with the student teachers. Four out of twelve student teachers claimed that some of the educational supervisors would only have a quick look at the lesson plan notebooks and not paying any visits. Furthermore, some supervisors impose difficult expectations over trainees. They fail to understand that it is a training period, a period of formative assessment rather than summative assessment. In some cases, there was a conflict in the comments and suggestions provided by supervisors. Furthermore, the method they used was open to questions as no systematic or standardized feedback techniques were followed. Because of this default, student teachers were forced to seek help from class teachers who also have their problems. Therefore, the supervision of teaching practice must be viewed as a very important task (Magdeline, 2013). Besides that, there is a debate between the program coordinator and some supervisors on what is the role of the supervisor? Is he a guide, a trainer or is he expected only to judge whether the trainee should pass or fail?

\section{Challenges related to student teachers}

All the four supervisors reported that some of the participants encounter difficulties in preparing a well-organized lesson plan that contains all the required elements and in alignment. This could be because student teachers did not receive enough training and inadequate feedback (Green et al. 1998). Three out of four supervisors said that some student teachers lack the required competence to carry out the teaching practice. For instance, they feel shy, standing in one place using only one voice tone level throughout the lesson, and rarely use their body language effectively. They added that some of the participants have various pronunciation errors, lack of fluency in English, and unclear handwriting which made the students struggle to read or copy what has been written by the teacher.

Another important issue observed by the supervisors during the teaching practice is the lack of classroom management. There are many pieces of evidence where the student teachers lost control over their students and the class ended in chaos. They dominate most of the talk in class and neither help low-level students to participate nor encourage collaborative learning to increase the level of interaction among students in the classroom. This is consistent with what was stated in a study carried out by Mosas (2019) which showed that classroom management is one of the "major challenges identified by student teachers during their teaching practice". Another striking challenge was mentioned by the supervisors is the overuse of technology at the expense of delivering the content. For instance, there is over-reliance on PowerPoint as a 
learning resource and thus neglecting the course and workbook. However, materials and aids were well prepared but were not adequately used.

On the other hand, the data indicated that some student teachers were enthusiastic and eager to teach using differentiated instructions. Some of them showed great ability in using various ways of teaching such as task-based learning, games, and songs-based learning. According to the supervisors, it was observed that some of the participants were very good at introducing the topic and activating the learners' prior knowledge using different techniques such as elicitation questions, pictures, and short videos. Some student teachers had clearly defined learning outcomes for their lessons and were then able to assess whether the learners had achieved these outcomes or not. It was also noted that some student teachers were willing to ask clarification questions immediately after the teaching sessions and keen to obtain constructive feedback promptly.

\section{Results related to the second research question}

Based on the results of the study, some suggestions are made to address the second research question: What are the possible suggestions to overcome these challenges?

First of all, the timing of the teaching practice program should start at the very beginning of the school semester to avoid any interruption or negative impact on the pre-prepared study schedules. It is also preferred to extend the teaching practice period for at least two semesters so that student teachers can have more practical teaching opportunities to implement what they have learned in college. Another important issue that needs to be considered is raising the schools' awareness of the importance of this program and offering every possible help to support the trainees. The supervisor as well as the school-teachers' role should be re-evaluated and clearly defined. Moreover, supervisors should devote more time for consultation and providing constructive feedback individually and in groups. More micro-teaching should be carried out by student teachers in the college where feedback can be provided by their classmates and instructors. Finally, conducting training workshops and meetings for university supervisors, cooperating teachers, and student teachers to discuss and arrange their specific roles and expectations (Ebrahim, et al, 2017).

\section{CONCLUSION}

The results of this study have indicated that the challenges faced by student teachers in the Faculty of Education at Tripoli University are similar to those found by other researchers as shown in the literature review. There were, however, three types of challenges. Firstly, challenges related to the schools where student teachers conducted their teaching practice. For example, the cooperative teachers did not provide the trainees with adequate support. The participants complained about the lack of facilities and the restrictions that hindered them from using a more advanced method of teaching. Secondly, there were challenges related to the supervisors. The results showed that student teachers did not receive constructive feedback on time, some supervisors did not devote enough time to discussing the student teachers' weaknesses and strengths after the teaching session. Thirdly, as for the challenges related to the student teachers themselves, some of them lacked the necessary confidence to carry out the teaching practice and others showed very little classroom management skills. Based on these findings, those responsible for the teaching practice program at the college should study these challenges and conduct a comprehensive review of the program with an emphasis on the role 
of the supervisor and the cooperative teacher. In addition, cooperation and coordination between the college and the schools should be strengthened and the importance of teaching practice should be stressed.

\section{References}

Abongdia,J.A ; Adu E.O \& Foncha, J.W. (2015). Pre-service Teachers' Challenges during Teaching Practice in One University in the Eastern Cape, South Africa. Int J Edu Sci, 11(1): 50-56 (2015)

Adeyanju, D. (2012) Reflective Teaching Practice Among Student Teachers: The Case in Tertiary Institution in Nigeria. Australian Journal of Teaching Education, 31(2)1-11.

Al-Momani, F. (2016). Challenges of practicum at college of education: Supervisors \& students' teachers perspective. International Journal of Novel Research in Humanity and Social Sciences 3, (3), 45-52.

Ball D. L., Thames, M. H., \& Phelps, G. (2008). Content knowledge for teaching: What makes it special? Journal of Teacher Education, 59, 389-407.

Confait, S. (2015) Beginning teachers' challenges in their pursuit of effective teaching practices, Cogent Education, 2:1, 991179, DOI: 10.1080/2331186X.2014.991179

Davidson, V. C. (2005). Introduction to Curriculum Studies. Nsukka: Anointed Fingers Educational Publishers.

Ebrahim,A. ; Eyadat, W and Alshammari, F. (2017) Challenges in Teaching Practice at the College of Education based on the Perceptions of Pre-Service Teachers: The Case for Kuwait University. $\quad$ DOI: 10.15804/tner.2017.49.3.20. http://www.educationalrev.us.edu.pl/e49/a20.pdf

Elmabruk, R. (2018). Teaching Practice Guide: A guide to teaching practice procedure and assessment for trainee teachers and supervisors, Faculty of Education Tripoli, The University of Tripoli, Libya. Retrieved from:

https://www.researchgate.net/publication/334108206_Teaching_Practice_Guide_A_guide_to _teaching_practice_procedure_and_assessment_for_trainee_teachers_and_supervisors

Elmabruk, R. (2020). JUDGING THE JUDGES: EXAMINING SUPERVISORS ASSESSMENT OF UNOBSERVABLE SKILLS IN DEVELOPED EFL TEACHING PRACTICE MODEL. Retrieved from:

https://www.researchgate.net/publication/339784200_JUDGING_THE_JUDGES_EXAMINI NG_SUPERVISORS_ASSESSMENT_OF_UNOBSERVABLE_SKILLS_IN_DEVE LOPED_EFL_TEACHING_PRACTICE_MODEL.

Green, L, Chedzoy, S., Harris, W., Mitchell, R., Naughton, C., Rolfe, L. and Stanton, W. (1998) A study of student teachers' perceptions of teaching the arts in primary schools. British Educational Research Journal 24, 95-107.

Nakpodia, E. D. (2011). Teacher and the student practice teaching programme in Nigeria educational system. International Journal of Educational Administration and Policy Studies 2 (3): 33-39.

Nasir, M. \& Zafar, I.(2018) Challenges Faced by Prospective Teachers during Teaching Practice: Connecting Theory to Practice. Bulletin of Education and Research August 2018, Vol. 40, No. 2 pp. 113-136.

Ngada, D. (2014), The benefits of mentoring. Educational Leadership,58:85-86 Ishmael N, Halse C \& Buchanan J 2000. Teaching Practice in the republic of Maldives: Issues and challenges. Pacific Asian Education, 12:40-56. 
Magdeline, M. (2013) Does Teaching Practice Effectively Prepare Student-Teachers to Teach Creative and Performing Arts? The Case of Botswana. International Journal of Higher Education Vol. 2, No. 2; 2013

Mosas, M. (2019). The challenges of teaching practice exercise among student teachers in Ogun State,

Nigeria. https://www.academia.edu/40199569/THE_CHALLENGES_OF_TEACHING_PRA CTICE_EXERCISE_AMONG_STUDENT_TEACHERS_IN_OGUN_STATE_NIG ERIA

SarÕçobana, A. (2010). Problems encountered by student-teachers during their practicum studies. Procedia Social and Behavioral Sciences 2 (2010) 707-711

Scott, L. C. (2015). The future of learning 3: What kind of Pedagogies for the 21st Century? Educational Research and Foresight, Working Papers. UNESCO.

Onyebukwa-Nwanoro Chikezie, J. (2017). Challenges of Student-Teachers during Teaching Practice in Nigeria. Journal of Educational Policy and Entrepreneurial Research ISSN: 2408-770X (Print), ISSN: 2408-6231 (Online) Vol. 4, N0.5. 2017. Pp 30-36 